\title{
Üniversite Öğrencilerinin Fakülte Yaşamının Nitelikleri, Akademik Özyeterlikleri ve Öznel İyi Oluşları Arasındaki Yordayıcı İlişkiler
}

The Predictive Relationship between University Students' Quality of Faculty Life, Academic Self-efficacy and Subjective Well-being

\author{
Tolga SEK $\dot{I}^{*}$ \\ Zeynep ŞİMŞİR ${ }^{* *}$ \\ Bülent DÍLMAÇ ${ }^{* * *}$ \\ Hasan Hüseyin BİRCAN ${ }^{* * *}$ \\ Erdal BAYKAN ${ }^{* * * * *}$
}

\begin{abstract}
Öz
$\mathrm{Bu}$ araştırmanın amacı üniversite öğrencilerinin fakülte yaşamının nitelikleri, akademik özyeterlikleri ve öznel iyi oluşları arasındaki yordayıcı ilişkileri ortaya koymaktır. Araştırmada genel tarama modelinin bir alt türü olan ilişkisel tarama modeli kullanılmıştır. Araştırma örneklem grubu 2016-2017 yılında Konya ilinde öğrenim görmekte olan öğrenciler arasından uygun/ elverişli örnekleme yöntemi ile seçilmiş 256 kadın, 62 erkek olmak üzere toplam 318 üniversite öğrencisinden oluşmaktadır. Katılmcıların yaşları 18-24 arasında olup yaş ortalaması 20.5'tir. Verilerin toplanmasında üniversite öğrencilerinin fakülte yaşam niteliklerini belirlemek amaciyla Fakülte Yaşam Niteliği Ölçeği, akademik öz-yeterliklerini belirlemek için Akademik Öz-yeterlik Ölçeği ve öznel iyi oluş düzeylerini belirlemek İçin Öznel İyi Oluş Ölçeği kullanılmıştır. Veriler "Yapısal Eşitlik Modeli”ne göre AMOS 16 Programı kullanılarak analiz edilmiştir. Araştırmadan elde edilen bulgulara göre, öğrencilerin fakülte yaşam niteliklerinin, akademik öz-yeterlik ve öznel
\end{abstract}

* Arş. Gör., Necmettin Erbakan Üniversitesi, Ahmet Keleşoğlu Eğitim Fakültesi, Konya, tlg.seki@gmail.com

** Arş. Gör., Necmettin Erbakan Üniversitesi, Ereğli Eğitim Fakültesi, Konya, zey.simsir.93@gmail.com

*** Prof., Necmettin Erbakan Üniversitesi, Ahmet Keleşoğlu Eğitim Fakültesi, Konya, bulentdilmac@gmail.com

$* * * *$ Prof., Necmettin Erbakan Üniversitesi, Sosyal ve Beşeri Bilimler Fakültesi, Konya,

***** Prof., Necmettin Erbakan Üniversitesi, Sosyal ve Beşeri Bilimler Fakültesi, Konya, 
iyi oluşları üzerinde doğrudan etkileri ve akademik öz-yeterliklerinin de öznel iyi oluş düzeyleri üzerinde doğrudan etkisi görülmüștür.

Anahtar Kelimeler: Fakülte yaşamı niteliği, akademik öz-yeterlik, öznel iyi oluş

\begin{abstract}
The aim of this research is to show the predictive relationships between the university life qualities, academic self-efficacy and subjective well-being of university students. The correlational research, a sub-type of the general screening model was used in the research. The study group consisted of 318 university students ( 256 female, 62 male) selected by convenience sampling method among the students in Konya in 2016-2017. The participants' ages ranged from 18 to 24 and the average age was 20.50. In order to determine the faculty life qualities of the university students, Faculty Life Quality Scale, Academic Self - Efficacy Scale to determine academic self - efficacy and Subjective Well - Being Scale to determine subjective well - being were used to collect data. The data were analyzed using the AMOS 16 Program according to the "Structural Equation Model". Findings from the research show that direct effects of students' faculty life qualities on academic self-efficacy and subjective well-being and direct effects of academic self-efficiency on subjective well-being.
\end{abstract}

Keywords: Quality of the faculty life, academic self-efficiency, subjective well-being

\title{
Giriş
}

Son zamanlarda üzerinde sıklıkla durulan yaşam kalitesi kavramı, sosyal bilimciler tarafından çeşitli şekillerde ele alınmaktadır. Siyaset, ekonomi, eğitim, sosyoloji, psikoloji gibi disiplinler bu kavrama kendi perspektiflerinden bir tanımlama getirmiştir (Eriş, 2012). Genel ve sürekli bir iyilik hali olarak ele alınan yaşam kalitesi, pozitif ve negatif deneyimler açısından değerlendirilmektedir (Linnakylä \& Brunell, 1996). Dünya sağlı örgütüne göre (1998), yaşam kalitesinin boyutları insanların fiziksel ve psikolojik sağlığını, aile içinde ve dışındaki sosyal ilişkilerini, inançlarını ve çevre ile etkileşimlerini kapsamaktadır. Yaşam kalitesinin önemli boyutlarından biri de eğitim ve okul yaşamıdır (Eriş, 2012; Ghotra, McIsaac, Kirk, \& Kuhle, 2016; Sarı, Ötünç \& Erceylan, 2007). Okul yaşam kalitesi, öğrencinin okul yaşamına dair deneyimlerinden tatmin olma derecesi ve okul hayatının belirli etki ve sonuçlarına dair birtakım duyguların sentezi olarak tanımlanır (Epstein \& McPartland, 1976; Leonard, 2002). Öğrencilerin okul yaşamının niteliğgi şu 5 unsurdan oluşmaktadır (Mitchell \& Spady, 1978):

1- Öğretmen-öğrenci ilişkileri

2- Sosyal bütünleşme (sınıf arkadaşları ve diğer insanlarla)

3- Okulun sunduğu imkânlar

4- Okul çalışmalarında başarılı olmak

5- Öğrenmeye duyulan zevk ve motivasyon

Literatürde okul yaşamının kalitesini ele alan araştırmalardan bir kısmı da üniversite yaşam kalitesi üzerine odaklanmıştır (Argon, \& Kösterelioğlu, 2009; Eriş, 2012; Özdemir, 
2012; Petruzzellis, D’Uggento, \& Romanazzi, 2006; Yllmaz \& Çokluk-Bökeoğlu, 2006). Bazı araştırmalarda okul yaşam kalitesi ile eş anlamlı bir şekilde kullanılan üniversite yaşam kalitesi, bir kısım araştırmacılar tarafından ayrı olarak ele alınmış ve farklı şekilde tanımlanmıştır (Sirgy, Grezeskowiak, \& Rahtz, 2007; Yılmaz \& Çokluk-Bökeoğlu, 2006). Sirgy ve diğerleri (2007) üniversite yaşam kalitesini öğrencilerin bir bütün olarak üniversite yaşamının genel kalitesini pozitif olarak değerlendirme derecesi olarak ifade etmiştir. Üniversite yaşamının kalitesi "fakülteden memnuniyet", "öğretim elemanlarından memnuniyet" ve "sinıf ortamı ve öğrenci ilişkilerinden memnuniyet" boyutlarından oluşmaktadır. Fakülteden memnuniyet, vakitlerinin çoğunu fakültede geçiren öğrencilerin fakülte yaşamına dair algılarını ve görüşlerini ifade etmektedir. Öğretim elemanlarından memnuniyet, öğrencilerin öğretim elemanları ile ilişkileri ve aldıkları eğitimle ilgili değerlendirmelerini içermektedir. Sınıf ortamı ve öğrenci ilişkilerinden memnuniyet ise eğitim-öğretim faaliyetlerine duymuş oldukları ilgiyi içermektedir (Bökeoğlu \& Yllmaz, 2007).

Hangi eğitim kademesinde olursa olsun okul yaşam doyumu öğrencilerin akademik başarısını, öznel iyi oluşunu, okuldaki iyi olma halini destekleyen bir durumdur (Epstein \& McPartland, 1976; Karatzias, Power, Flemming, Lennan, \& Swanson, 2002; Sarı, Ötünç \& Erceylan, 2007). Yapılan araştırmalarda okul yaşam kalitesinin akademik başarıyı pozitif olarak etkilediği görülmüştür (Heyneman, \& Loxley, 1983; İlmen, 2010). Öğrencilerin kaliteli bir okul yaşantısına sahip olması akademik başarılarının yanı sıra öğrencilerin kendilerini akademik yönden yeterli hissetme düzeylerini ifade eden akademik öz-yeterliklerini de pozitif yönde etkilemektedir (Pekel, 2016).

Kuramsal temelleri sosyal-bilişsel teoriye dayanan öz-yeterlik kavramı, bireyin belirli görevleri yerine getirme ve öğrenme kapasitesine olan inancını ifade etmektedir (Bandura, 1997). Bireylerin yaşamının ilk yıllarından itibaren oluşmaya başlayan öz-yeterlik inancının gelişmesinde ailenin, yakın çevrenin, akranların, okul yaşamının ve öğretmenlerin rolü büyüktür (Pajares, \& Schunk, 2001).

Bireylerin yeterlik algıları bir işte göstereceği performansı doğrudan ya da dolaylı olarak etkilemektedir. Nitekim öz-yeterlik, bireylerin hedeflerini, sonuç beklentilerini, isteklerini, duygusal eğilimlerini, sosyal çevredeki fırsatlar ve engellere dair algılarını şekillendirir (Bandura, 2000; Bandura, 1997). İnsan yaşamında önemli bir yeri olan öz-yeterlik algısı kişilerin geçmişte deneyimlemiş olduğu performansı (performans deneyimleri), içinde bulunduğu duygusal durum, çevresindeki insanların başarılı olduğunu görmek (dolaylı yaşantılar) ve bir davranışın başarılı bir şekilde ortaya koyabileceğine dair başkaları tarafından yapılan telkin (sözel ikna) yoluyla şekillenir (Bandura, 1997). Bu unsurların pozitif olması kişinin bir işte başarılı olacağına dair öz-yeterlik algısını artırır.

Öz-yeterlik kavramı son 20 yıldır, öğrencilerin öğrenmelerinin ve motivasyonlarının yordayıcısı olarak ele alınmaktadır. Eğitimciler öğrencilerin akademik yeteneklerine dair inançlarının başaracaklarına dair motive olmalarında önemli bir rolü olduğunun uzun zamandır farkındadır (Zimmerman, 2000). Algılanan akademik öz-yeterlik, öğrencinin akademik bir görevi başarıyla tamamlayabileceğine dair inancı olarak tanımlanabilir (Ekici, 2012; Yılmaz, 
Gürçay \& Ekici, 2007). Öğrencilerin algılamış oldukları öz-yeterlik, etkisini dört önemli süreç yoluyla gösterir. Bunlar bilişsel, duygusal, motivasyonel ve seçme süreçleridir. Öğrencilerin kendi öğrenme davranışlarını ve akademik aktivitelerini düzenleyebileceklerine olan inancı isteklerini, motivasyon düzeylerini ve akademik başarılarını etkiler (Bandura, 1993). Literatürde akademik öz-yeterlik inancının öğrencilerin başarı düzeyleri, akademik motivasyonları, akademik başarı not ortalamaları, ders çalışma yaklaşımları, akademik performansları ve uyumları ile ilişkisine işaret eden çok sayıda çalışma vardır (Alemdağ, Erman \& Yılmaz, 2014; Chemers, Hu, \& Garcia, 2001; Choi, 2005; Çağırgan Gülten, \& Soytürk, 2013; Çuhadar, Gündüz, \& Tanyeri, 2013; Ferla, Valcke, \& Cai, 2009; Zajacova, Lynch, \& Espenshade, 2005).

Akademik öz-yeterlik düzeyi yüksek öğrencilerin, kapasitelerinden şüphe duyan öğrencilerle karşılaştırıldığında, derse katılım için daha hazırlıklı oldukları, daha çok ve daha kararlı çalışma temposuna sahip oldukları ve karşılaştıkları zorluklarda daha az duygusal tepkiler verdikleri bilinmektedir (Bandura, 1997; Pajares, \& Schunk, 2001). Tüm bu unsurların ve akademik başarının okul yaşamının niteliğini yansıttığı düşünüldüğünde, üniversite öğrencilerinin okul yaşam kalitesinin değerlendirilmesinin önemi daha iyi anlaşılabilir. Nitekim akademik özyeterlik algısı yaşla birlikte daha net bir hal almakta ve öğrencilerin yaşamları ile ilgili seçimlerini yaptığı üniversite yıllarında daha büyük bir önem kazanmaktadır (Özsüer, Gözde, Uyanik, \& Ergün, 2011).

Akademik alanda en önemli bilişsel boyutlardan birini oluşturan öz-yeterlik, bireyin sorunlarla başa çıkma potansiyelini artırırken, düşük düzeydeki özyeterlik olumsuz duygulara ve kaygıya yol açmaktadır. (Bandura, 1997). Akademik, duygusal, sosyal ve genel öz-yeterlikler öğrencilerin depresyon, anksiyete, olumsuz benlik algısı, somatizasyon ve hostilite düzeyleri ile negatif ilişkili (Telef \& Karaca, 2011) iken öznel iyi oluşları ile pozitif ilişkilidir (Certel, Bahadır, Saracaloğlu, \& Varol, 2015; Telef \& Ergün, 2013).

Pozitif psikolojinin üzerinde durduğu kavramlardan biri olan öznel iyi oluş, kişinin yaşam doyumuna ve sahip olduğu olumlu-olumsuz duygulara ilişkin sübjektif ve bilişsel değerlendirmesidir (Diener, 1984). Zaman zaman mutluluk ile eş anlamlı olarak kullanılan öznel iyi oluş kavramı mutluluktan daha spesifik bir anlama sahiptir (Diener, 2006). Öznel iyi oluş olumlu duygulanım, olumsuz duygulanım ve yaşam doyumu olmak üzere 3 boyuttan oluşmaktadır. Olumlu duygulanım sevinç, memnuniyet, sevgi gibi olumlu duyguları kapsarken, olumsuz duygulanım endişe, stres, suçluluk ve öfke gibi duyguları kapsamaktadır. Yaşam doyumu da kişinin hem genel hem de özel hayatta (evlilik, iş, aşk ve arkadaşlık..vb.) sahip olduğu doyumu ifade etmektedir (Diener, Suh, \& Oishi, 1997). Diener, Suh, Lucas ve Smith (1999), bu boyutlara yaşam alanlarından alınan doyumu da ekleyerek kavramın çerçevesini genişletmişlerdir.

Öznel iyi oluş, öz-yeterlik kavramı gibi bilişsel ve duyuşsal yönleri olan bir kavramdır. Öznel iyi oluşun duygusal olumlu ve olumsuz duygulanım boyutları duyuşsal yönünü, yaşam doyumu ve yaşam alanlarına (iş, okul, evlilik, arkadaşlık) ilişkin doyum ise bilişsel yönünü oluşturmaktadır (Diener, 1984; Diener ve diğ., 1999). Bireylerin öznel iyi oluşunun yüksek olması, olumlu duygulanımın olumsuz duygulanımdan fazla olmasına ve yaşamının kalitesine 
dair bilişsel yargılarının pozitif olmasına bağlıdır. Bireyin sahip olduğu bilişsel yargıları ve pozitif duyguları yaşamının çeşitli alanlarında olabilmekte ve bunların toplamı genel yaşam doyumunu oluşturmaktadır (Tuzgöl Dost, 2004).

Literatürde öznel iyi oluş üzerine yapılan çalışmalar öznel iyi oluşun çeşitli değiş̧kenlerle ilişkisi olduğunu ortaya koymuştur. Cinsiyet, yaş, (Eryılmaz \& Ercan, 2011), kişilik özellikleri (Diener \& Lucas, 1999; Doğan, 2012), yaşam amaçları, psikolojik ihtiyaç doyumu (İlhan \& Özbay, 2016), milletlerin sosyal, kültürel ve ekonomik karakteristiği (Diener, Diener \& Diener, 1995), gelir durumu (Diener, \& Oishi, 2000), medeni durum (Diener, Gohm, Suh, \& Oishi, 2000), sosyal destek ve benlik saygısı (Saygın, \& Arslan, 2009), olumlu gelecek beklentisi (Eryılmaz, 2011), başa çıkma stilleri (Işık \& Bedel, 2015) bunlardan bazısıdır.

İnsan ömrünün yaklaşık üçte birinin okul sıralarında geçtiği ve öğrencilerin de günlerinin yaklaşı üçte birinin okulda geçtiği düşünüldügünde, insan yaşamında niceliksel olarak büyük bir zaman dilimini kapsayan okul yaşamının nitelik açısından da içinin doldurulması önemlidir. Kaliteli yaşamın nasıl olacağı konusunda sıkı sık tartışmaların yapıldığı günümüzde, okul yaşam kalitesini bilhassa üniversite yıllarındaki okul yaşam kalitesini göz ardı etmek mümkün görünmemektedir. Bu araştırmada da üniversite öğrencilerinin fakülte yaşam niteliklerinin öznel iyi oluş ve akademik öz-yeterlik düzeylerinin önemli bir yordayıcısı olup olmadığının ortaya koyulması amaçlanmıştır. Ayrıca akademik öz-yeterlik düzeyinin, öznel iyi oluş üzerindeki yordama gücünün ortaya koyulması amaçlanmıştır. Literatürde fakülte yaşam nitelikleri, öznel iyi oluş ve akademik özyeterlik değişkenlerinin bir arada ele alındığ çalışmaların sınırlılığı ve günümüz eğitim uygulamaları göz önünde bulundurulduğunda araştırma sonuçlarının hem teori hem uygulamalara katkı getireceği düşünülmektedir.

\section{Yöntem}

\section{Araştırmanın Modeli}

Araştırmada, üniversite öğrencilerinin fakülte yaşamının nitelikleri, akademik öz-yeterlikleri ve öznel iyi oluşları arasındaki yordayıcı ilişkileri ortaya koymak amaçlanmıştır. Araştırmada nicel araştırma desenlerinden genel tarama modelinin bir alt türü olan ilişkisel tarama modeli kullanılmıştır. İlişsisel tarama, iki ya da daha fazla değişken arasındaki ilişkiyi belirlemek ve neden-sonuç ile ilgili ipuçları elde etmek amacıyla yapılan araştırma modelidir (Büyüköztürk, Kılıç-Çakmak, Akgün, Karadeniz ve Demirel, 2008; Creswell, 2016).

\section{Örneklem Grubu}

Araştırmanın çalışma evrenini 2016-2017 eğitim öğretim yılında Konya ilinde öğrenim görmekte olan üniversite öğrencileri oluşturmaktadır. Araştırmanın çalışma örneklemi uygun/ elverişli örnekleme yöntemi ile seçilmiş 256 kadın, 62 erkek olmak üzere 318 üniversite öğrencisinden oluşmaktadır. Uygun/ elverişli örnekleme katılımcılara erişimin kolay olduğu ve uygunluğu nedeniyle kullanılan olasılığa dayalı olmayan örnekleme türüdür (Creswell, 2016). 
Katılımcılar iki üniversite ve altı fakültede öğrenim gören, çalışmaya gönüllü olarak katılan öğrencilerden oluşmaktadır. Katılımcıların yaşları 18-24 arasında olup yaş ortalaması 20.5’tir.

\section{Veri Toplama Araçları}

Fakülte Yaşam Niteliği Ölçeği: Yılmaz ve Çokluk Bökeoğlu (2006) tarafından Türkçeye uyarlanmıştır. Ölçek 37 madde ve üç alt boyuttan oluşmaktadır. «Fakülteden Memnuniyet alt boyutu» için açıkladığı varyans \%23 ve cronbach alpha 0.75, «Öğretim Elemanlarından Memnuniyet alt boyutu» için açıkladığ 1 varyans \%31 ve cronbach alpha 0.83 , «Sinıf Ortamı ve Öğrenci İlişkilerinde Memnuniyet alt boyutu» için açıkladığı varyans \%34 ve cronbach alpha 0.67 bulunmuştur. Ölçeğin tümü için cronbach alpha 0.87 olarak bulunmuştur. Yapılan çalışmada ölçeğin örneklem grubuna ait cronbach alpha katsayısı 0.89 olarak bulunurken, doğrulayıcı faktör analizi sonucu modelin uyum indeksleri sırası ile $\mathrm{x}^{2} / \mathrm{sd}=1.82, \mathrm{RMSEA}=0.05, \mathrm{SRMR}=0.06$ olarak bulunmuştur.

AkademikÖzyeterlikÖlçeği: Yılmaz, Gürçayve Ekici (2007) tarafından üniversite öğrencilerinin akademik özyeterliklerinin saptanması amacıyla Türkçeye uyarlanmıştır. Orijinaline uygun olarak tek boyut ve 7 maddeden oluşmaktadır. Ölçeğin KMO değeri 0,83 ve Bartlett testi sonucu $\chi 2=1230,09$ ( $\mathrm{p} \leq .05)$ olarak bulunmuştur. Ölçeğin açılkanan varyans toplamı \%45 ve cronbach alpha güvenilirlik değeri .79 olarak bulunmuştur. Ölçek maddelerinin faktör yükleri .50 ile .82 arasında değişmektedir. Yapılan çalışmada ölçeğin örneklem grubuna ait cronbach alpha katsayısı 0.82 olarak bulunurken, doğrulayıcı faktör analizi sonucu modelin uyum indeksleri sırası ile $\mathrm{x}^{2} /$ $\mathrm{sd}=1.19, \mathrm{RMSEA}=0.02, \mathrm{SRMR}=0.03$ olarak bulunmuştur.

Öznel İyi Oluş Ölçeği: Tuzgöl-Dost (2005) tarafından bireylerin öznel iyi oluşlarını saptayabilmek için geliştirilmiştir. Öznel iyi oluş ölçeği 46 maddeden oluşan 5’li likert tipi bir ölçektir. Ölçek yaşamını kendi geçmişi ve başkalarının hayatı ile kıyaslama, olumlu ve olumsuz duygular, amaçlar, kendine güven, iyimserlik, ilgi duyulan etkinlikler, arkadaşlık ilişkileri, geleceğe bakış, aile ilişkileri, başkalarının yaşamına imrenme, yaşamın zorluklarıyla baş etme, karamsarlık olmak üzere on iki alt boyuttan oluşmaktadır ve açıklanan toplam varyans 63.83'dür. ÖİÖ’nin Cronbach Alpha güvenirlik katsayısı .93 olarak bulunmuştur. Test-tekrar test yöntemi uygulanmış ve pearson momentler çarpım korelasyon katsayısı .86 olarak bulunmuştur. Yapılan çalışmada ölçeğin örneklem grubuna ait cronbach alpha katsayısı 0.94 olarak bulunurken, doğrulayıcı faktör analizi sonucu modelin uyum indeksleri sırası ile $\mathrm{x}^{2} / \mathrm{sd}=2.48, \mathrm{RMSEA}=0.05$, $\mathrm{SRMR}=0.07$ olarak bulunmuştur.

\section{Verilerin Analizi}

Araştırmada üniversite öğrencilerinin fakülte yaşamlarının nitelikleri, akademik özyeterlikleri ve öznel iyi oluşları arasındaki yordayıcı ilişkileri ortaya koymak amacıyla elde edilen veriler "Yapısal Eşitlik Modeli”ne göre AMOS 16 Programı kullanılarak analiz edilmiştir. Yapısal eşitlik modellemesi bir kuramsal modeli test etmek için gözlenen ve gizil değişkenler arasındaki nedensel ve karşılıklı ilişkileri ortaya koyan istatistiksel bir yaklaşımdır (Shumacker ve Lomax, 2004). 


\section{Bulgular}

Elde edilen modelde (X2=249.045, df=92, p<.001) üç exogenus, (fakülteden memnuniyet, öğretim elemanlarından memnuniyet, sınıf ortamı ve öğrenci ilişkilerinde memnuniyet) iki endogenous (akademik öz-yeterlik ve öznel iyi oluş) veri yer almaktadır. Modelde gösterilen yolların her biri istatistiksel olarak anlamlı bulunmuştur. The Bentler-Bonett normed fit index (NFI), The Tucker-Lewis coefficient fit index (TLI) ve diğer uyum indeksleri modelin kabul edilebilir düzeyde uyumlu olduğunu göstermiştir (Tablo 1). Modelde yer alan endogenous verileri arasındaki iki yönlü korelasyonların her biri yüksek değerlere sahiptir ve istatistiksel olarak anlamlıdır. Bu durum, çalışmada kullanılan ölçeklerin alt boyutlarının sahip olduğu korelasyon değerlerinden de etkilenmektedir.

Tablo I.

Yapısal Eşitlik Modelinin Uyumuna Illişkin İstatistiksel Değerler

\begin{tabular}{cccc}
\hline Ölçüm & İyi Uyum & $\begin{array}{c}\text { Kabul Edilebilir } \\
\text { Uyum }\end{array}$ & $\begin{array}{c}\text { Modelin Uyum İndeksi } \\
\text { Değerleri }\end{array}$ \\
\hline$\left(\mathrm{X}^{2} / \mathrm{sd}\right)$ & $\leq 3$ & $\leq 4-5$ & 2.70 \\
$\mathrm{RMSEA}$ & $\leq 0.05$ & $0.06-0.08$ & 0.07 \\
SRMR & $\leq 0.05$ & $0.06-0.08$ & 0.06 \\
NFI & $\geq 0.95$ & $0.94-0.90$ & 0.91 \\
CFI & $\geq 0.97$ & $\geq 0.95$ & 0.95 \\
GFI & $\geq 0.90$ & $0.89-0.85$ & 0.91 \\
AGFI & $\geq 0.90$ & $0.89-0.85$ & 0.90 \\
TLI & $\geq 0.95$ & $0.94-0.90$ & 0.92 \\
\hline
\end{tabular}

Tablo 1'de yer alan uyum değerleri incelendiğinde, $\mathrm{X}^{2} / \mathrm{sd}=2.70, \mathrm{RMSEA}=0.07$, SRMR $=$ $0.06, \mathrm{NFI}=0.91, \mathrm{CFI}=0.95, \mathrm{GFI}=0.91, \mathrm{AGFI}=0.90$ ve TLI $=0.92$ olarak bulunmuştur. Genel olarak, modelin istenen düzeyde uyum değerlerine sahip olduğu anlaşılmaktadır (Bollen, 1989; Browne ve Cudeck, 1993; Byrne, 2010; Hu ve Bentler, 1999; Kline, 2011; Tanaka ve Huba, 1985). Test edilen tek faktörlü model Şekil 1'de gösterilmiştir. Modelde gösterilen tüm yollar 0.001 düzeyinde anlamlıdır. 


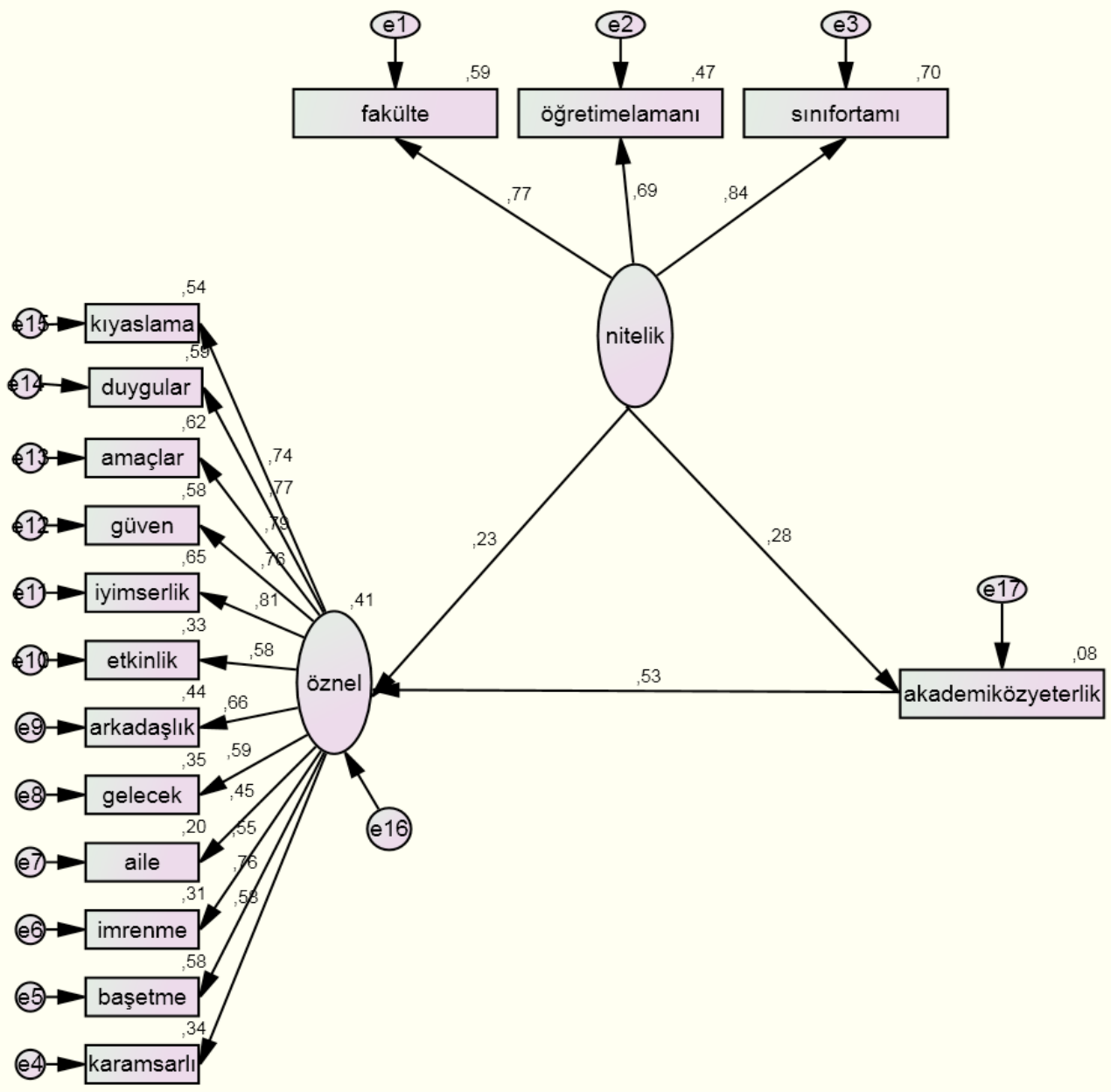

Şekil I. Modele ilişkin yol analizi

Tablo 2.

Ergenlerin Sahip Oldukları Değerler ile Öznel liyi Oluş ve Sosyal Görünüşü Kaygı Düzeyleri Arasındaki Arasındaki Yordayıı Illişkilerine Yönelik Model

\begin{tabular}{llccccc}
\hline $\begin{array}{l}\text { Yordayıcı } \\
\text { Değişken }\end{array}$ & Bağımlı Değişken & $\begin{array}{c}\text { Toplam } \\
\text { Etki }\end{array}$ & $\begin{array}{c}\text { Doğrudan } \\
\text { Etki }\end{array}$ & $\begin{array}{c}\text { Dolaylı } \\
\text { Etki }\end{array}$ & $\begin{array}{c}\text { Standart } \\
\text { Hata }\end{array}$ & $\begin{array}{c}\text { Kritik } \\
\text { Değer }\end{array}$ \\
\hline Fakülte Yaşam Niteliği & Öznel İyi Oluşs & 0.23 & 0.23 & 0 & 0.12 & $3.69^{*}$ \\
Fakülte Yaşam Niteliğĭ & Akademik Özyeterlik & 0.28 & 0.28 & 0 & 0.43 & $4.59^{*}$ \\
Akademik Özyeterlik & Öznel İyi Oluş & 0.53 & 0.53 & 0 & 0.20 & $7.98^{*}$ \\
\hline
\end{tabular}

a Toplam etki $=$ Doğrudan etki + Dolaylı etki, ${ }^{*} \mathrm{p}<0.01,{ }^{* *} \mathrm{p}<0.05$. 
Şekil 1' deki model ve Tablo 2' deki veriler incelendiğinde akademik öz-yeterlik algısını etkileyen en önemli bağımsız değişkenin ( $\mathrm{t}=4.59, \mathrm{p}<0.01)$ fakülte yaşam niteliği değişkeni olduğu görülmektedir. Bu faktöre ilişkin bağlantı katsayı değeri $\beta=0.29$ olarak belirlenmiştir. Üniversite öğrencilerinin fakülte yaşam niteliği ile akademik öz-yeterlikleri arasındaki yordayıcı ilişkiler incelendiğinde, pozitif yönlü doğrusal bir ilişki olduğu belirlenmiştir. Başka bir ifadeyle elde edilen bulgular üniversite öğrencilerinin fakülte yaşam nitelikleri arattıkça akademik öz-yeterlik düzeylerinin de artacağını ortaya koymaktadır.

Test edilen modelde öznel iyi oluş düzeyini etkileyen en önemli değişkenin $(t=7.98, p<0.01)$ akademik öz-yeterlik olduğu görülmektedir. Bu faktöre ilişkin bağlantı katsayı değeri $\beta=0.55$ olarak belirlenmiştir. Üniversite öğrencilerin akademik öz-yeterlik düzeyleri ile öznel iyi oluşları arasındaki yordayıcı ilişkileri incelendiğinde, pozitif yönlü doğrusal bir ilişki olduğu belirlenmiştir. Başka bir ifadeyle elde edilen bulgular, üniversite öğrencilerinin akademik özyeterlik düzeyleri artmasıyla, üniversite öğrencilerinin öznel iyi oluşlarının da artacağını ortaya koymaktadır.

Ayrıca şekildeki model incelendiğinde, üniversite öğrencilerinin öznel iyi oluşlarını etkileyen en önemli ikinci değişkenin $(t=3.69 p<0.01)$ fakülte yaşam niteliği değişkeni olduğu görülmektedir. Bu faktöre ilişkin bağlantı katsayı değeri $\beta=0.38$ olarak bulunmuştur. Üniversite öğrencilerinin fakülte yaşam niteliği ile öznel iyi oluş arasındaki yordayıcı ilişkileri incelendiğinde, pozitif yönlü doğrusal bir ilişki olduğu belirlenmiştir. Başka bir ifadeyle elde edilen bulgular, üniversite öğrencilerinin fakülte yaşam niteliğinin artmasıyla öznel iyi oluşlarının artacağını ortaya koymaktadır.

\section{Tartışma}

Araştırmada elde edilen sonuçlara göre; üniversite öğrencilerinin fakülte yaşam niteliği ile akademik öz-yeterlik arasındaki yordayıcı ilişkiler incelendiğinde, pozitif yönlü doğrusal bir ilişki olduğu belirlenmiştir. Ayrıca üniversite öğrencilerinin akademik öz-yeterlik düzeyleri ile öznel iyi oluşları arasındaki yordayıcı ilişkiler incelendiğinde, pozitif yönlü doğrusal bir ilişki olduğu belirlenmiştir. Yaşam kalitesinin boyutlarından biri olarak düşünebileceğimiz okul yaşam kalitesi, öğrencilerin seçim yaparak geldikleri, sosyal, kültürel ve sportif etkinliklere katılabilecekleri, düşünce sistemlerini geliştirebilecekleri yükseköğretim kurumlarında bilhassa önemlidir (Bökeoğlu \& Yılmaz, 2007). Alan yazında üniversite öğrencilerinin fakülte yaşam niteliğinin, cinsiyet, yaş düzeyi ve öğrenim görülen fakülte (Bökeoğlu \& Yllmaz, 2007; Özdemir, 2012), öğrenim görülen sınıf düzeyi ve öğrenim görülen bölüme (Özdemir, Kılınç, Öğdem, \& Er, 2013) göre anlamlı farklılaşma gösterdiğini; okul kültürü (Argon \& Kösterelioğlu, 2009) ile pozitif yönde, okula yabancılaşma algısı ile negatif yönde (Ayık \& Ataş-Akdemir, 2016) ilişkili olduğunu ortaya koyan çalışmalar mevcuttur. Bu araştırmanın sonuçları ile paralellik gösteren çalışmalara bakıldığında; Pekel (2016), üniversite öğrencilerinde üniversite yaşam kalitesi ile akademik özyeterlik düzeyleri arasındaki ilişkiyi incelemiştir. Yapılan çalışmada üniversite yaşam kalitesi ile akademik öz-yeterlik arasında pozitif yönde anlamlı ilişki olduğu tespit edilmiştir.. Güldü (2015), 
öğrenciler ile gerçekleştirdiği çalışmada öğrencilerin görüşleri doğrultusunda okul metaforları, akademik öz-yeterlikleri ile lise yaşam kalitesi arasındaki ilişkiyi incelemiştir. Yapılan çalışmada Lise Yaşam Kalitesi Ölçeğinin tüm alt boyutları ile akademik öz-yeterlik puanları arasında pozitif yönlü anlamlı ilişki bulunmuştur. Kandemir (2014), üniversite öğrencilerinin akademik ertelemenin nedenleri üzerine yaptı̆̆ı araştırmada, yaşam doyumu, akademik öz-yeterlik, öz denetim gibi kavramları incelemiştir. Yapılan araştırmada, yaşam doyumu ile akademik özyeterlik arasında pozitif yönlü anlamlı ilişki tespit edilmiştir.

Tamannaeifar ve Motaghedifard’’n (2014) üniversite öğrencileri ile öznel iyi oluş, öz-yeterlik ve yaratıcılık arasındaki ilişkileri ortaya koymak amacıyla gerçekleştirdikleri araştırmada, öznel iyi oluş ve öz-yeterlik arasında pozitif yönde anlamlı ilişki bulmuştur. Benzer şekilde Telef ve Ergün (2013), yaptıkları çalışmada öğrencilerin akademik, sosyal ve duygusal öz-yeterliklerin öznel iyi oluş üzerindeki yordayıcı gücünü incelemiştir Yapılan araştırmada akademik öz-yeterliğin öğrencilerinin öznel iyi oluşlarını yordadığı saptanmıştır. Telef ve Karaca (2011), ergenlerin öz-yeterlikleri ve psikolojik semptomlarını incelemişlerdir. Yapılan araştırmada ergenlerin akademik, duygusal, sosyal ve genel öz-yeterlikleri ile öğrencilerin depresyon, anksiyete, olumsuz benlik algısı düzeyleri ile negatif yönü ilişkili bulmuşlardır. Certel, Bahadır, Saracaloğlu ve Varol (2015), lise öğrencileri ile gerçekleştirdikleri çalışmalarında öğrencilerin öz-yeterlikleri ile öznel iyi oluşları arasındaki ilişkiyi incelemişlerdir. Yapılan çalışmada akademik öz-yeterlik ile öznel iyi oluş arasında pozitif yönlü ilişki bulmuşlardır. İlgili literatür ve yapılan araştırmalar incelendiğinde okul yaşamının niteliği ile akademik öz-yeterlik arasında, ayrıca akademik öz-yeterlik ile öznel iyi oluş arasında pozitif yönlü doğrusal bir ilişki bulunduğu sonucuna ulaşabiliriz. Elde edilen sonucun konu ile ilgili yapılmış araştırmalarla birbirini destekler nitelikte olduğunu söylemek mümkündür.

Yapılan araştırmanın son bulgusu, üniversite öğrencilerinin fakülte yaşam niteliği ile öznel iyi oluş arasındaki yordayıcı ilişkiler incelendiğinde, pozitif yönlü doğrusal bir ilişki olduğu belirlenmiştir. Başka bir ifadeyle elde edilen bulgular, üniversite öğrencilerinin fakülte yaşam niteliğinin artmasıyla öznel iyi oluşlarının artacağını ortaya koymaktadır. Literatüre bakıldı̆̆ında Karatzias, Power \& Swanson (2001), gerçekleştirdikleri çok kültürlü araştırmalarında okul yaşam kalitesi, okulun etkileri, okul stresi, kendine saygı, iyi olma gibi kavramları incelemişlerdir. Yapılan çalışmada okul yaşam kalitesi puanları yüksek olan öğrencilerin kendine saygı ve iyi olma puanlarının da yüksek olduğu görülmüştür.

İlmen (2010), ortaokul öğrencileri ile gerçekleştirdiği çalışmasında okul yaşam kalitesinin akademik başarı üzerindeki etkisini incelemiştir. Yapılan çalışmada, okul yaşam kalitesinin akademik başarı üzerinde oldukça etkili bir faktör olduğu bulunmuştur. Leonard (2002), gerçekleştirdiği çalışmada okula yönelik olumsuz duygular besleyen öğrencilerin, daha düşük başarı gösterdiğini ve daha sık devamsızlık yaptığını bulmuştur. Mok ve Flynn’n (1998), 5932 onikinci sınıf öğrencisinden elde ettikleri bulgulara göre okulun yaşam kalitesi, öğrencilerin akademik başarısındaki varyansın \%40’nı açıklamaktadır. Ayrıca yapılan çalışmalar akademik öz-yeterlik ile akademik başarı arasında pozitif yönlü doğrusal bir ilişki olduğunu göstermektedir (Siriparp, 2015). Öz-yeterlik düzeyi yüksek öğrencilerde akademik başarının yanı sıra yüksek 
akademik motivasyon gözlenmektedir (Saracoğlu \& Dinçer, 2009). Akademik başarının yüksek olmasının da öznel iyi oluş ve yaşam doyumu üzerinde pozitif etkisi vardır (Dost, 2010). Ayrıca akademik motivasyon bireylerin öznel iyi oluşu artırma stratejilerinin kullanımını artırmaktadır (Eryllmaz, 2010). Cenkseven-Önder ve Sari (2009) öğretmenlerin okul yaşam kalitesi, tükenmişlik ve öznel iyi oluş düzeyleri arasındaki ilişkileri inceledikleri çalışmaya göre ise okul yaşam kalitesi öznel iyi oluşun önemli bir yordayıcısı olarak bulunmuştur. Yapılan çalışmalar incelendiğinde okul yaşamının niteliğinin öznel iyi oluş üzerinde doğrudan etkisinin yanı sıra akademik öz-yeterlik, akademik başarı gibi aracı değişkenler vasıtasıyla dolaylı etkisinden de bahsedilebilir. İlgili literatür incelendiğinde okul yaşamının niteliğinin öznel iyi oluş üzerinde doğrudan ve dolaylı etkisinin bulunduğunu söylemek mümkündür. Yapılan araştırmadan elde edilen sonuçlara göre fakülte yaşam niteliği ile öznel iyi oluş arasındaki pozitif yönlü doğrusal ilişki, ilgili literatür ile birbirini destekler niteliktedir.

Bütün bu bilgiler doğrultusunda üniversite öğrencilerin yaşamlarının büyük bir kısmını fakültede geçirdiklerini göz önünde bulundurursak üniversite öğrencilerinin fakülte yaşamının nitelikleri, akademik öz-yeterlikleri ve öznel iyi oluşlarını konu alan bu çalışmanın ülkemizin geleceği olan üniversite gençliğinin daha iyi tanınmasına katkı sağlayacağı düşünülmektedir. Ancak, yapılan araştırma bir takım sinıllılıkları da beraberinde getirmektedir. Bu bağlamda araştırmanın değişik üniversitelerde ve farklı öğretim programlarına devam eden (önlisans, doktora vb.) üniversite öğrencileri ile tekrarlanmasının, bu araştırma sonuçlarının genellenebilirliğine katkı sağlayacağı düşünülmektedir. 


\section{Kaynakça}

Alemdağ, C., Erman, Ö. N. C. Ü., \& Yılmaz, A. K. (2014). Beden eğitimi öğretmeni adaylarının akademik motivasyon ve akademik öz-yeterlikleri. Spor Bilimleri Dergisi, 25(1), 23-35.

Argon, T., \& Kösterelioğlu, M. A. (2009). Üniversite öğrencilerinin üniversite yaşam kalitesi ve fakülte kültürüne ilişkin algıları. Electronic Journal of Social Sciences, 8(30), 43-61.

Ayık, A., \& Ataş-Akdemir, Ö. (2016). Öğretmen adaylarının okul yaşam kalitesi ve okula yabancılaşma algıları arasındaki ilişki. Kuram ve Uygulamada Eğitim Yönetimi Dergisi, 21(4), 429-452.

Bandura, A. (1993). Perceived self-efficacy in cognitive development and functioning. Educational Psychologist, 28(2), 117-148.

Bandura, A. (1997). Self-efficacy: The exercise of control. New York: Freeman and Company.

Bandura, A. (2000). Exercise of human agency through collective efficacy. Current Directions in Psychological Science, 9(3), 75-78.

Bollen, K. A. (1989). A new incremental fit index for general structural equation models. Sociological Methods and Research, 17(3), 303-316.

Bökeoğlu, Ö. Ç., \& Yılmaz, K. (2007). Analysis of university students' views about the quality of faculty life using various variables. Ankara University, Journal of Faculty of Educational Sciences, 40(2), 179204.

Browne, M. W., \& Cudeck, R. (1993). Alternative ways of assessing model fit. Sage Focus Editions, 154, 136136.

Büyüköztürk, Ş., Kılıç-Çakmak, E., Akgün, Ö. E., Karadeniz, Ş. ve Demirel, F. (2008). Bilimsel araştırma yöntemleri. Ankara: Pegem.

Byrne, B. M. (2010). Structural equation modeling with AMOS: Basic concepts, applications, and programming (2nd Ed.). New York: Taylor and Francis.

Cenkseven-Önder, F., \& Sari, M. (2009). The Quality of school life and burnout as predictors of subjective well-being among teachers. Educational Sciences: Theory and Practice, 9(3), 1223-1235.

Certel, Z., Bahadır, Z., Saracaloğlu, A. S., \& Varol, S. R.(2015). Lise öğrencilerinin öz-yeterlikleri ile öznel iyi oluş düzeyleri arasındaki ilişkinin incelenmesi. Eğitim ve Öğretim Araştırmaları Dergisi, 4(2), 307-218.

Chemers, M. M., Hu, L. T., \& Garcia, B. F. (2001). Academic self-efficacy and first year college student performance and adjustment. Journal of Educational psychology, 93(1), 55.

Choi, N. (2005). Self efficacy and self concept as predictors of college students' academic performance. Psychology in the Schools, 42(2), 197-205.

Çağırgan Gülten, D., \& Soytürk, İ. (2013). İlköğretim 6. sınıf öğrencilerinin geometri öz-yeterliklerinin akademik başarı not ortalamaları ile ilişkisi. Mehmet Akif Ersoy Üniversitesi Eğitim Fakültesi Dergisi, 13(25), 55 - 70.

Creswell, J. W. (2016). Arastirma deseni: Nitel, nicel ve karma yöntem yaklasimlari. (S. B. Demir, Çev.). Ankara: Eğiten Kitap.

Çuhadar, C., Gündüz, Ş., \& Tanyeri, T. (2013). Bilgisayar ve öğretim teknolojileri eğitimi bölümü öğrencilerinin ders çalışma yaklaşımları ve akademik öz-yeterlik algıları arasındaki ilişkinin incelenmesi. Mersin Üniversitesi Eğitim Fakültesi Dergisi, 9(1), 251-259.

Diener, E. (1984). Subjective well-being. Psychological bulletin, 95(3), 542-575.

Diener, E. (2006). Guidelines for national indicators of subjective well-being and ill-being. Journal of happiness studies, 7(4), 397-404. 
Diener, E., Diener, M., \& Diener, C. (1995). Factors predicting the subjective well-being of nations. Journal of Personality and Social Psychology, 69(5), 851.

Diener, E., Gohm, C. L., Suh, E., \& Oishi, S. (2000). Similarity of the relations between marital status and subjective well-being across cultures. Journal of Cross-Cultural Psychology, 31(4), 419-436.

Diener, E., \& Lucas, R. E. (1999). 11 personality and subjective well-being. D. Kahneman, \& N. Schwartz (Eds.). Well-being: Foundations of Hedonic Psychology (sf. 213-229) içinde. New York: Russel Sage Foundation.

Diener, E., \& Oishi, S. (2000). Money and happiness: Income and subjective well-being across nations. Culture and Subjective Well-Being, 8, 185-218.

Diener, E., Suh, E. M., Lucas, R. E., \& Smith, H. L. (1999). Subjective well-being: Three decades of progress. Psychological bulletin, 125(2), 276.

Diener, E., Suh, E., \& Oishi, S. (1997). Recent findings on subjective well-being. Indian journal of clinical psychology, 24, 25-41.

Doğan, T. (2012). Beş faktör kişilik özellikleri ve öznel iyi oluş. Doğuş Üniversitesi Dergisi, 14(1), 56-64.

Dost, M. T. (2010). An examination of subjective well-being and life satisfaction of students attending to universities in South Africa and Turkey. Egitim ve Bilim, 35(158), 75.

Ekici, G. (2012). Akademik öz-yeterlik ölçeği: Türçeye uyarlama, geçerlik ve güvenirlik çalışması. Hacettepe Üniversitesi Eğitim Fakültesi Dergisi, 43(43), 174-185.

Epstein, J. L., \& McPartland, J. M. (1976). The concept and measurement of the quality of school life. American Educational Research Journal, 13(1), 15-30.

Eriş, H. M. (2012). Üniversite öğrencilerinin yaşam kalitesi düzeylerinin bazı değişkenlere göre incelenmesi. (Yayımlanmamış yüksek lisans tezi). Hacettepe Üniversitesi, Ankara.

Eryılmaz, A. (2010). Ergenlerde öznel iyi oluşu artırma stratejilerini kullanma ile akademik motivasyon arasındaki ilişki. Klinik Psikiyatri, 13, 77-84.

Eryılmaz, A. (2011). Ergen öznel iyi oluşu ile olumlu gelecek beklentisi arasındaki ilişkinin incelenmesi. Dusunen Adam: Journal of Psychiatry \& Neurological Sciences, 24(3), 209-215.

Eryılmaz, A., \& Ercan, L. (2011). Öznel iyi oluşun cinsiyet, yaş grupları ve kişilik özellikleri açısından incelenmesi. Türk Psikolojik Danışma ve Rehberlik Dergisi, 4(36), 139-149.

Ferla, J., Valcke, M., \& Cai, Y. (2009). Academic self-efficacy and academic self-concept: Reconsidering structural relationships. Learning and Individual Differences, 19(4), 499-505.

Ghotra, S., McIsaac, J. L. D., Kirk, S. F., \& Kuhle, S. (2016). Validation of the "Quality of Life in School" instrument in Canadian elementary school students. PeerJ, 4, 1-17.

Güldü, S. (2015). Liselerde okuyan öğrencilerin görüşleri doğrultusunda okul metaforları, akademik öz yeterlik ve lise yaşam kalitesi arasındaki ilişkinin incelenmesi. (Yayımlanmamış yüksek lisans tezi). Zirve Üniversitesi, Gaziantep.

Heyneman, S. P., \& Loxley, W. A. (1983). The effect of primary-school quality on academic achievement across twenty-nine high-and low-income countries. American Journal of sociology, 88(6), 11621194.

Hu, L. T. ve Bentler, P. M. (1999). Cutoff criteria for fit indexes in covariance structure analysis: Conventional criteria versus new alternatives. Structural Equation Modeling: A Multidisciplinary Journal, 6(1), $1-55$.

Işık, E., \& Bedel, A. (2015). Ergenlerde başa çıkma stratejileri ile öznel iyi oluş arasındaki ilişkiler. Selçuk Üniversitesi Sosyal Bilimler Enstitüsü Dergisi, (34), 53-60. 
İlhan, T., \& Özbay, Y. (2016). Yaşam amaçlarının ve psikolojik ihtiyaç doyumunun öznel iyi oluş üzerindeki yordayıcı rolü. Türk Psikolojik Danışma ve Rehberlik Dergisi, 4(34), 109-118.

İlmen, A. (2010). Okul grubunun okul yaşam kalitesi ve akademik başarı üzerindeki etkisi. (Yayımlanmamış yüksek lisans tezi). Yüzüncü Yll Üniversitesi, Van.

Kandemir, M. (2014). Akademik ertelemenin yordayıcıları: Sorumluluk, başarı/başarısızlığa yönelik yükleme stilleri ve akademik öz-yeterlik inançları. Eğitim ve Bilim, 39(171), 99-114.

Karatzias, A., Power, K. G., \& Swanson, V. (2001). Quality of school life: Development and preliminary standardisation of an instrument based on performance indicators in Scottish secondary schools. School Effectiveness and School Improvement, 12(3), 265-284.

Karatzias, A., Power, K. G., Flemming, J., Lennan, F., \& Swanson, V. (2002). The role of demographics, personality variables, and school stress on predicting school satisfaction/dissatisfaction: Review of the literature and research findings. Educational Psychology, 22(1), 33-50.

Kline, R. B. (2011), Principles and practice of structural equation modeling. New York: The Guilford Press.

Leonard, C. A. R. (2002). Quality of school life and attendance in primary schools. (Unpublished doctoral dissertation). University of Newcastle, Australia.

Linnakylä, P. \& Brunell, V. (1996). Quality of school life in the Finnish and Swedish speaking schools in Finland. M. Binkley, \& K. Rust, T. Williams (Eds.) In Reading literacy in an international perspective (pp..203 - 217). U.S.: Department of Education Office of Educational Research and Improvement.

Mok, M., \& Flynn, M. (1998). Effect of Catholic school culture on students' achievement In the Higher School Certificate Examination: A multilevel path analysis. Educational Psychology, 18(4), 409432.

Özdemir, M. (2012). Üniversite öğrencilerinin okul yaşamının niteliğine ilişkin algılarının cinsiyet ve fakülte değişkenlerine göre incelenmesi. Kuram ve Uygulamada Eğitim Yönetimi, 2(2), 225-242.

Özdemir, S., Kılınç, A. Ç., Öğdem, Z., \& Er, E. (2013). Eğitim fakültesi öğrencilerinin fakülte yaşamının niteliğine ilişkin memnuniyet düzeylerinin çeşitli değişkenler açısından incelenmesi. Journal of Higher Education \& Science/Yüksekögretim ve Bilim Dergisi, 3(3), 228-235.

Özsüer, S., Inal, G., Uyanik, Ö., \& Ergün, M. (2011). Afyon Kocatepe Üniversitesinde öğrenim gören öğrencilerin akademik özyeterlik inanç düzeylerinin incelenmesi. Afyon Kocatepe University Journal of Social Sciences, 13(2), 113-125.

Pajares, F., \& Schunk, D. (2001). The development of academic self-efficacy. Wigfield \& J. Eccles (Eds.), Development of achievement motivation (sf. 1-27) içinde. San Diego: Academic Press.

Pekel, A. (2016). Spor yöneticiliği bölümünde öğrenim gören öğrencilerinin akademik özyeterlikleri ve üniversite yaşam kalitesi arasındaki ilişkinin incelenmesi. (Yayımlanmamış yüksek lisans tezi). Erciyes Üniversitesi, Kayseri.

Petruzzellis, L., D’Uggento, A. M., \& Romanazzi, S. (2006). Student satisfaction and quality of service in Italian universities. Managing Service Quality, 16(4), 349-364.

Saracoğlu, S., \& Dinçer, B. (2009). A study on correlation between self-efficacy and academic motivation of prospective teachers. Social and Behavioral Sciences, 1(1), 320-325.

Sarı, M., Ötünç, E., \& Erceylan, H. (2007). Liselerde okul yaşam kalitesi: Adana ili örneği. Kuram ve Uygulamada Ĕ̆itim Yönetimi, 50(50), 297-320.

Saygın, Y., \& Arslan, C. (2009). Üniversite öğrencilerinin sosyal destek, benlik saygısı ve öznel iyi oluş düzeylerinin incelenmesi. Selçuk Üniversitesi Ahmet Keleşoğlu Eğitim Fakültesi Dergisi, 28, 207 222. 
Schumacker, R. E. ve Lomax, R. G. (2004). A beginner's guide to structural equation modelling. London: Lawrence Erlbaum Associates, Publishers.

Sirgy, M. J., Grzeskowiak, S., \& Rahtz, D. (2007). Quality of college life (QCL) of students: Developing and validating a measure of well-being. Social Indicators Research, 80(2), 343-360.

Siriparp, T. (2015). Examining self-efficacy and achievement in an educational research course. ProcediaSocial and Behavioral Sciences, 171, 1360-136

Tamannaeifar, M. R., \& Motaghedifard, M. (2014). Subjective well-being and its sub-scales among students: The study of role of creativity and self-efficacy. Thinking Skills and Creativity, 12, 37-42.

Tanaka, J. S. ve Huba, G. J. (1985). A fit index for covariance structure models under arbitrary GLS estimation. British Journal of Mathematical and Statistical Psychology, 38(2), 197-201.

Telef, B. B., \& Ergün, E. (2013).Lise öğrencilerinin öznel iyi oluşlarının yordayıcısı olarak öz-yeterlik. Kuramsal Eğitimbilim Dergisi, 6(3), 423-433.

Telef, B. B., \& Karaca, R. (2011). Ergenlerin öz-yeterliklerinin ve psikolojik semptomlarının incelenmesi. Mustafa Kemal Üniversitesi Sosyal Bilimler Enstitüsü Dergisi, 8(16), 499-518.

The World Health Organization Quality of Life Assessment (1998). Development and general psychometric properties. Soc Sci Med,46, 1569-85.

Tuzgöl Dost, M. (2004). Üniversite öğrencilerinin öznel iyi oluş düzeyleri. (Yayımlanmamış Yüksek Lisans Tezi). Hacettepe Üniversitesi, Ankara.

Tuzgöl Dost, M. (2005). Ruh sağlığı ve öznel iyi oluş. Eurasian Journal of Educational Research, 20, 223-231.

Yılmaz, K., \& Çokluk-Bökeoğlu, Ö. (2006). Fakülte yaşamının niteliği ölçeğinin geçerlik ve güvenirlik çalışması. Türk Ĕ̆itim Bilimleri Dergisi, 4(2), 201-210.

Yılmaz, M., Gürçay, D., \& Ekici, G. (2007). Akademik öz-yeterlik ölçeğinin Türkçe’ye uyarlanması. Hacettepe Üniversitesi Eğitim Fakültesi Dergisi, 33(33), 253-259.

Zajacova, A., Lynch, S. M., \& Espenshade, T. J. (2005). Self-efficacy, stress, and academic success in college. Research in Higher Education, 46(6), 677-706.

Zimmerman, B. J. (2000). Self-efficacy: An essential motive to learn. Contemporary Educational Psychology, 25(1), 82-91. 